\title{
Development of Discovery Learning-Based Science Supplementary Textbooks to Improve Students' Creative Thinking
}

\author{
Adya Rosa ${ }^{1}$, Alben Ambarita ${ }^{2}$, Lilik Sabdaningtyas ${ }^{3}$, Dwi Yulianti ${ }^{4}$ \\ DOI: $10.35445 /$ alishlah.v13i3.897
}

\section{Article Info}

Keywords: Development; Textbooks; Discovery Learning; Creative Thinking

Kata kunci:

Pengembangan;

Buku Ajar;

Pembelajaran

Penemuan;

Berpikir Kreatif

\section{Abstract}

Students' inability to think creatively in scientific classes is the impetus for this study. An appropriate Discovery Learning-based Science Supplement Textbook is the goal of this research, as is a description of its ability to boost students' creative thinking on Heat and Transfer Themes. Borg \& Gall's theory is the basis for research and development. The study's target audience was fifthgraders in Metro Timur District elementary schools. Using the purposive sampling method, 28 students from class V were selected for the study. Mixed quantitative and qualitative methods were used in the data analysis process. The Discovery Learning-Based Science Supplement Textbook was found to be practicable and useful in enhancing students' creative thinking abilities. Through the validation results of material experts, media experts, and linguists, it may be concluded that the project is feasible. According to the preand post-test scores of creative thinking in the experimental class, the category "Effective Enough" achieved an N-gain of $61 \%$. In general, the students' responses indicated that the Discovery Learning-based Science Supplementary Textbook could help students think more creatively, according to the findings.

\begin{abstract}
Abstrak
Penelitian dan pengembangan ini dilatar belakangi oleh permasalahan rendahnya berpikir kreatif peserta didik pada mata pelajaran IPA. Tujuan penelitian adalah untuk menghasilkan Buku Ajar Suplemen IPA berbasis Discovery Learning yang layak dan mendeskripsikan efektivitas Buku Ajar Suplemen IPA berbasis Discovery Learning untuk meningkatkan berpikir kreatif peserta didik pada Tema Panas dan Perpindahannya. Penelitian dan pengembangan merujuk teori Borg \& Gall. Populasi penelitian adalah peserta didik kelas V SD Kecamatan Metro Timur. Pengambilan sampel penelitian menggunakan teknik purposive sampling, kelas V sebesar 28 peserta didik. Teknik analisis data dilakukan secara mixed antara kuantitatif dan kualitatif. Hasil penelitian menunjukkan bahwa Buku Ajar Suplemen IPA Berbasis Discovery Learning layak digunakan, serta efektif untuk meningkatkan berpikir kreatif peserta didik. Kelayakan dibuktikan melalui hasil validasi ahli materi, ahli media dan ahli bahasa, dengan kriteria "sangat valid, sangat tuntas, dan dapat digunakan". Efektivitas dibuktikan dengan hasil perhitungan skor pretest dan posttest berpikir kreatif pada kelas eksperimen diperoleh $\mathrm{N}$-gain sebesar 61\% dengan kategori "Cukup Efektif". Tanggapan peserta didik secara keseluruhan menunjukkan hampir seluruh peserta didik menyatakan Buku Ajar
\end{abstract}

\footnotetext{
${ }^{1}$ Universitas Lampung, Indonesia,

Email: adya.rosa54@gmail.com

2 Universitas Lampung, Indonesia

Email: alben-ambarita57@yahoo.com

3 Universitas Lampung, Indonesia,

Email: lilik_sabdaningtyas2yahoo.co.id

4 Universitas Lampung, Indonesia

Eemail: safira_shodiq@yahoo.com
}

Vol.13 (3) December 2021.

Received: July 30, 2021; Received: August 12, 2021; Accepted: November 27, 2021; Available online date month year

This is an open access article under a Creative Commons Attribution-NonCommercial-ShareAlike 4.o International License. 


\section{INTRODUCTION}

Educators in education have an important role in the classroom to create a conducive learning process. According to educators, there are at least three tasks, namely educating, teaching, and training (Sanger \& Osguthorpe, 2011). The task of educating places more emphasis on the formation of soul, character, and personality based on values. The teaching task emphasizes the development of reasoning abilities, and the training task emphasizes the development of the ability to apply technology by training various skills (Bao \& Koenig, 2019). Educators have the opportunity to change the way students learn to have good creative thinking skills in students. To create good learning conditions in the classroom, in the learning process, an educator is required to be able to organize, select and implement learning strategies that are suitable for the conditions of students and the environment being taught so that the learning objectives have been set can be achieved.

(Chiappetta \& Kobala, 2010) define science as a way of thinking, a way of investigating, a body of knowledge, and its interaction with technology and society. It can be interpreted that there are dimensions of ways of thinking, how to investigate, building science, and its relation to technology and society in science.

Learning science is not enough to stand up, lecture and explain the material in science textbooks. This is because science lessons emphasize providing direct experience and practical activities to develop competencies so that students can explore and understand the natural surroundings scientifically. Science education is directed to finding out "know" and "do" to help students gain a deeper understanding of the natural surroundings. One of the materials in learning science in schools with the environment in everyday life is heat and its transfer. We study heat, and its transfer cannot be separated from the factors of the natural environment (Sahudra, Taher, \& Kemal, 2021). A heat and its transfer that we often occur in our daily life. (Rusmono, 2012) suggests that learning is a cognitive process that occurs within a person. Learning comes from cognitive theory, tasks and learning processes are analyzed according to prevailing circumstances, and learning situations are determined. Appropriate information structures are made to obtain the desired learning outcomes (Gürses et al., 2010). According to (Ahmad 2013), learning is an activity carried out by a person intentionally in a conscious state to acquire a new concept, understanding or knowledge to allow for relatively permanent changes in behaviour both in thinking, feeling, and in acting.

Based on the preliminary research results show that in learning science, educators need to describe the subject matter so that it becomes an appropriate and complete textbook that can guide students to think creatively because students' creative thinking skills need to be improved. To improve creative thinking, students need active learning. It is known that by using-based science supplement textbooks, discovery learning, there is a significant difference in increasing creative thinking skills. So that in 21st-century learning, it is important to improve students' creative thinking with a creative learning culture that must be instilled in schools. By using based science supplement textbooks discovery learning can also improve students' creative thinking skills, logical reasoning, use of questions, and is a more creative way to solve problems. It is hoped that changes to more creative thinking will occur if this science textbook is used in an organized and dynamic manner in learning activities. Educators do not apply science learning to determine an action to solve problems with creative thinking skills.

The textbooks used in science learning in schools today are not the result of educators' development. Therefore, the existing textbooks only emphasize the problem material without showing how to find it and do not provide opportunities for students to be able to find concepts 
from a material independently. The existence of textbooks in science learning is to help students improve their creative thinking skills. So it is necessary to develop a science supplementary textbook based on discovery learning so that students' creative thinking skills can be trained.

The development of science supplement textbooks discovery learning is a success in learning, especially to develop students' creative thinking skills and is also very dependent on the supplementary textbooks used. According to (Mbulu, 2001), the application of textbooks open up opportunities for students to learn at their own pace, according to their ways and use different techniques to solve certain problems based on their respective background knowledge and habits.

In a previous study, (Marlina, Hardigaluh, \& Yokhebed, 2015) states that the potential local module can improve students' environmental care attitudes. The school environment and the resulting local potential bring students closer to existing environmental problems, thereby fostering a caring attitude towards the environment. (Ramdhani, Usodo, \& Subanti, 2017) found that there is an increase in student achievement scores after they are taught using the Discovery learning method. Similarly, Ahour and Mostafee (2009) argue that discovery learning improves the speaking performance of EFL students. In addition, discovery learning is effective for improving students' critical thinking.

Along with science textbooks that must be carried out by every educator, the selection of approaches, models, and learning methods in each learning activity must be appropriate. The learning textbook model used must make students feel challenged to participate in learning activities. One of the learning textbook models that educators can choose and develop is the model discovery learning.-based science textbooks are Discovery learning used in this study because they have the advantage of developing creative thinking skills, especially in the science learning process. So the researchers are interested in researching "Development of-based science supplement textbooks discovery learning to improve students' creative thinking".

This research aims to improve students' creative thinking with science supplement textbooks discovery learning that is suitable for use on the theme of heat and its displacement for class V SD. As well as knowing the effectiveness of-based science supplement textbooks discovery learning to improve students' creative thinking on the theme of heat and its transfer for fifth-grade elementary school.

\section{METHOD}

The development method used in this development is research and development or Research and Development (R\&D). (Sugiyono, 2010) states that research and development (Research and Development) is a research method used to develop or validate products used in education and learning. This research is called R\&D because it develops products that will be used to determine students' psychomotor abilities in certain basic competencies. This research develops Discovery Learning-Based Science Supplement Textbook to Improve Students' Creative Thinking Ability.

Researchers use the steps to be able to conduct research and development according to (Sutopo \& Pamungkas, 2017) are research and information gathering, planning, development of initial product forms, preliminary field tests, major product revisions, main field tests, operational product revisions, operational field testing, final product revision, as well as dissemination and implementation. This research was conducted at SD Negeri 7 Metro Timur, Lampung, Indonesia.

\section{FINDINGS AND DISCUSSION}

The researchers obtained several problems in learning, namely 1) The low creative thinking of students indicated by $65.25 \%$ included in the category of low creative thinking, 2) the questionnaire needs of educators showed 4 out of 7 educators had not maximally in increasing the mastery of thematic learning materials for students and has not been able to overcome problems in learning; 3) of 7 educators have not directed students to think creatively every time they solve 
problems in learning; 4) the results obtained as many as $60 \%$ of students stated that they were not required to think creatively in every learning activity; 5) as many as $67 \%$ of students stated that in thematic learning there was a lack of discovery methods to support the creative thinking of their students.

Based on the results of the questionnaire analysis of the need for a learning model, it is increasingly demanding to develop a Discovery Learning Model in science learning. Therefore, the researcher developed a Discovery Learning-Based Supplementary Textbook product for science learning, the theme of Heat and Transfer, to improve the creative thinking of fifth-grade elementary school students.

\section{Product Planning Results}

Planning in the development of science supplement textbooks is as follows:

\section{a) Curriculum Analysis}

Curriculum analysis activities are carried out to determine the suitability of the objectives needed in the development of textbooks. The development of this textbook refers to the implementation of the 2013 curriculum. The textbook developed in this study is a discovery learning-based science supplement textbook for fifth-grade elementary school theme 6 "Heat and its displacement".

\section{b) Determining KI and KD}

The development of science supplement textbooks includes science subjects. The following core competencies and basic competencies used in education are presented in the following table.

Table 1. Selection of KI and KD

\begin{tabular}{|c|c|c|}
\hline No & Aspect & Information \\
\hline 1 & $\begin{array}{l}\text { Core } \\
\text { Competencies } \\
\text { KI-3 }\end{array}$ & $\begin{array}{l}\text { Understanding factual knowledge by } \\
\text { observing (hearing, seeing, reading) and } \\
\text { asking questions based on curiosity about } \\
\text { himself, God's creatures and their } \\
\text { activities, and the objects he encounters at } \\
\text { home and school. }\end{array}$ \\
\hline 2 & $\begin{array}{l}\text { Basic } \\
\text { Competence } \\
\text { (KD) }\end{array}$ & $\begin{array}{l}\text { IPA } \\
\text { Apply the concept of heat transfer in daily } \\
\text { life }\end{array}$ \\
\hline
\end{tabular}

\section{Product Development Results}

a. Introductory section; cover, pre-words, advantages of textbooks, mapping of $\mathrm{KI}$ and $\mathrm{KD}$, parts of textbook contents (sub-themes, indicators, learning objectives).

b. Student activities are based on discovery learning (simulation, problem statement, data collection, data processing, verification, generalization). 
Table. 2. Results of the validation of discovery learning-based science supplementary textbooks

\begin{tabular}{|c|c|c|c|c|l|}
\hline \multirow{2}{*}{ No. } & \multirow{2}{*}{ Rated Aspect } & \multicolumn{2}{|c|}{$\begin{array}{c}\text { Total Score } \\
\text { Rating }\end{array}$} & \multirow{2}{*}{$\begin{array}{c}\text { Average } \\
\text { (\%) }\end{array}$} & Criteria \\
\cline { 3 - 4 } & & I & II & & \\
\hline \multirow{2}{*}{$\mathbf{1}$} & Material Expert & 59 & - & \multirow{2}{*}{$92 \%$} & Very Valid, very thorough, usable \\
\cline { 2 - 4 } & Percentage (\%) & $92 \%$ & - & & \\
\hline \multirow{2}{*}{$\mathbf{2}$} & Media Expert & $50 \%$ & $66 \%$ & \multirow{2}{*}{$81 \%$} & Very Valid, very thorough, usable \\
\cline { 2 - 4 } & Percentage (\%) & $69 \%$ & $91 \%$ & & \\
\hline \multirow{2}{*}{$\mathbf{3}$} & Linguist & 58 & - & \multirow{2}{*}{$98 \%$} & Very Valid, very thorough, usable \\
\cline { 2 - 4 } & Percentage (\%) & $96 \%$ & - & & \\
\hline
\end{tabular}

Table 3. Initial Trial Results and Final Test Results

\begin{tabular}{|l|l|l|}
\hline No & Initial Trial Results & Final Trial Results \\
\hline 1 & $\begin{array}{l}\text { Validity (23 questions consist of 19 } \\
\text { valid questions and 4 invalid questions) }\end{array}$ & Validity (19 valid questions) \\
\hline 2 & $\begin{array}{l}\text { Reliability (from 23 questions get an r } \\
\text { value of 0.84307 with a very high } \\
\text { category) }\end{array}$ & $\begin{array}{l}\text { Reliability (from 19 questions, the value of } \\
\text { r count is 0.84307 with a very high category) }\end{array}$ \\
\hline 3 & $\begin{array}{l}\text { Difficulty Level (of 23 questions } \\
\text { consisting of 9 difficult questions, 12 } \\
\text { medium questions and 2 easy questions) }\end{array}$ & $\begin{array}{l}\text { Dificult Level (of 19 questions consisting of } \\
\text { and 2 easy questions) 9 medium questions } \\
\text { and }\end{array}$ \\
\hline 4 & $\begin{array}{l}\text { Distinguishing Power (of 23 } \\
\text { questions consisting of 2 good questions, } \\
16 \text { enough questions, and 5 bad } \\
\text { questions) }\end{array}$ & $\begin{array}{l}\text { Distinguishing Power (of 19 questions, 2 } \\
\text { are good, 16 are sufficient, and 1 is bad) }\end{array}$ \\
\hline 5 & $\begin{array}{l}\text { Pretest 65,25\% with low category } \\
\text { creative thinking }\end{array}$ & $\begin{array}{l}\text { Posttest 85,80\% with creative thinking } \\
\text { category }\end{array}$ \\
\hline
\end{tabular}

\section{Student Response}

Based on the results of the assessment of science supplement textbooks using student response questionnaires on aspects of attractiveness, usefulness, and readability of textbooks after learning, the results obtained are;

Table 4. Results of Attractiveness, Usefulness, and Readability Assessments for small group trial class students

\begin{tabular}{lcl}
\hline \multicolumn{1}{c}{ Rated Aspect } & $\begin{array}{c}\text { Percentage } \\
\text { (\%) }\end{array}$ & Criteria \\
\hline Attractiveness & 89 & Very Interesting \\
\hline Useulness & 87 & Very Helpful
\end{tabular}




$\begin{array}{lll}\text { Legibility } & 81 & \text { Very Readable }\end{array}$

\section{Product Final Revision}

Revision of the final product is carried out based on the results of field trials and findings when the product is tested. Based on the field trials that have been carried out, the results show that there are still errors in the wording of the textbook. This is a revision material for product improvement. /'Based on the theoretical and empirical validation results, the developed science supplement textbook product was not revised. So, it is feasible and effective enough to be used to improve students' creative thinking in learning the theme of heat and its displacement.

Theoretical feasibility is obtained from the assessment results of 3 product validation experts, namely material experts, linguists, and media experts. Based on the average percentage of results from the three product validation experts, $90 \%$ with the Very Valid, very complete category can be used.

The empirical feasibility of textbooks is based on the results of the analysis of the items. The analysis includes validity, reliability, level of difficulty, discriminating power, and student responses. Based on the calculation, there are 18 questions for field trials on theme six heat and the transfer is based on discovery learning to improve students' creative thinking.

Data analysis from the final test showed that the Discovery Learning-Based Science Supplement Textbook was effective enough to improve the creative thinking skills of fifth-grade elementary school students on the theme of heat and its displacement. The effectiveness of textbooks was measured using the results of the $\mathrm{N}$-gain calculation on the pretest and post-test on creative thinking. The results of the calculation of the $\mathrm{N}$-gain score of the average value on the tests that have been given to the pretest and post-test after being given treatment. The average test score on the pretest is known to be 65.25 as many as 28 students, then the average score at the post-test is 85.80 with an average $\mathrm{N}$-Gain of 0.7 (high category). Based on these results, there is a difference in test scores between the pretest and post-test. These differences become the basis for determining the effectiveness of the use of this Discovery Learning-Based Science Supplementary Textbook

\section{CONCLUSION}

The Discovery Learning-Based Science Supplement Textbook was developed to be feasible to use, theoretically feasible and empirically feasible. Theoretically feasible, this is evidenced by the results of material expert validation obtaining a percentage value of $92 \%$ and the criteria "very valid, very complete, and usable", media expert validation obtaining a percentage value of $81 \%$ and the criteria "very valid, very complete, and can be used", validation of linguists obtained a percentage value of $98 \%$ and the criteria "very valid, very complete, and can be used". Based on the suggestions and validation results, the Discovery Learning-Based Science Supplementary Textbook is declared valid and feasible to be used as a learning resource in learning in fifth grade elementary school.

Empirical feasibility is based on the results of the analysis of the validity test with an average of 0.4359 with sufficient validity interpretation, reliability 0.7658 with a high correlation interpretation, 0.355 difficulty level with moderate difficulty interpretation, difference power of 0.482 with good discriminatory index, and participant responses. $86 \%$ of students with attractiveness criteria are very interesting, usefulness criteria are very useful, and readability criteria are very legible.

The Discovery Learning-Based Science Supplement Textbook is effective enough to be used in the learning process for class V Metro students to improve creative thinking. This is evidenced by the creative thinking of students who obtained a pretest of 65.25 with a low category, increased 
to a post-test of 85.80 with a moderately creative category and an N-gain score of $61 \%$ with a moderately effective category.

\section{REFERENCES}

Bao, L., \& Koenig, K. (2019). Physics education research for 21 st century learning. Disciplinary and Interdisciplinary Science Education Research, 1(1), 1-12.

Chiappetta, E. L., \& Kobala, T. (2010). Science Instruction in the Middle and Secondary School. Boston: Allyn \& Bacon.

Gürses, A., Çağlayan, D., Doğar, Ç., Yolcu, H. H., Korucu, M. E., \& Köktepe, S. (2010). The investigation of harmony between teachers' thoughts on nature of learning and their applied teaching activities in teaching and learning process. Procedia-Social and Behavioral Sciences, 9, 1014-1019.

Marlina, R., Hardigaluh, B., \& Yokhebed, Y. (2015). Pengembangan modul pengetahuan lingkungan berbasis potensi lokal untuk menumbuhkan sikap peduli lingkungan mahasiswa pendidikan biologi. Jurnal Pengajaran MIPA, 2O(1), 94-99.

Mbulu, J. (2001). Pendekatan dan Bentuk Pengajaran Individual. Kota Malang: Universitas Negeri Malang.

Ramdhani, M. ., Usodo, B., \& Subanti, S. (2017). Discovery Learning With Scientific Approach to Geometry. Journal of Physics: Cons. Series, 895(1), 1-6.

Rusmono, S. P. D. P. B. (2012). Learning Itu Perlu Untuk Meningkatkan Porfesionalitas Guru. Bogor: Ghalia Indonesia.

Sahudra, T. M., Taher, A., \& Kemal, I. (2021). E-Learning Development Management with The Schoology Improving Geographic Learning Literation. Journal of Education Technology, 5(1).

Sanger, M. N., \& Osguthorpe, R. D. (2011). Teacher education, preservice teacher beliefs, and the moral work of teaching. Teaching and Teacher Education, 27(3), 569-578.

Sugiyono. (2010). Metode Penelitian Pendidikan Pendekatan Kuantitatif, kualitatif, dan R\&D. Bandung: Alfabeta.

Sutopo, H., \& Pamungkas, W. (2017). Developing mathematics mobile game to enhance learning for children. 2017 IEEE International Conference on Computational Science and Engineering (CSE) and IEEE International Conference on Embedded and Ubiquitous Computing (EUC), 1, 191-197. IEEE. 